\title{
Ólögmæt dreifing örvandi lyfseðilsskyldra lyfja meðal unglinga í 10. bekk
}

\author{
Gísli Kristófersson ${ }^{1}$ geðhjúkrunarfræðingur, Ársæll Arnarsson² faraldsfræðingur, \\ Guðmundur Heimisson ${ }^{3}$ próffræðingur, Dagbjörg Sigurðardóttir $\left.{ }^{4}\right|^{2}$ knir
}

\section{Á G R I P}

Inngangur: Athyglisbrestur og ofvirkni (ADHD) er taugaproskaröskun sem kemur yfirleitt fram fyrir 7 ára aldur. Örvandi lyf eru mikið notuð til meðhöndlunar á pessum kvilla hér á landi, en fela í sér hættu á ávanabindingu, misnotkun og lyfjaflakki, pað er að pau séu notuð af öđrum einstaklingi en peim sem læknir skrifaði lyfseðil fyrir. Pessari rannsókn var ætlað að svara pví hversu algengt slíkt lyfjaflakk væri meðal unglinga á íslandi.

Efniviður og aðferðir: Hér er byggt á gögnum sem safnað var i íslenskum hluta ESPAD-rannsóknarinnar (European School Survey Project on Alcohol and Other Drugs) um vímuefnaneyslu 10. bekkinga.

Niðurstöður: Af 2306 nemendum sem tóku pátt í könnunni sögðust $91 \%$ (2098) aldrei hafa fengið slík lyf uppáskrifuð en 9\% (208) sögðu svo vera.
Strákar voru rúmlega helmingi líklegri til að hafa fengið örvandi lyf uppáskrifuð en stúlkur. Tæplega 18\% unglinganna í könnuninni kvaðst hafa dreift lyfjunum sínum til annarra með einhverjum hætti. Peir unglingar eru einnig margfalt líklegri til að sýna af sér annars konar áhættuhegðun. Umræða: Lyfjaflakk örvandi lyfja á meðal 10. bekkinga á Íslandi er algengt miðað við erlendar rannsóknir par sem hlutfallið er nær 5-10\%. Á sama tíma sýna niðurstöđurnar fram á mikilvægi pess að̃ vandað sé til verka hvað varðar aðbúnað og umgjörð slíkar notkunar pví til mikils er að vinna, bæði fyrir barnið sjálft og pá sem komast á ólöglegan hátt yfir lyfin og neyta peirra.

\section{Inngangur}

Athyglisbrestur og ofvirkni (ADHD, Attention Deficit Hyperactivity Disorder) er taugaproskaröskun sem kemur yfirleitt fram fyrir 7 ára aldur og getur haft víðtæk áhrif á daglegt líf, nám og félagslega aðlögun. ${ }^{1}$ Samkvæmt nýlegum faraldsfræðilegum rannsóknum er talið að 6-10\% barna og um 5\% fullorðinna séu með pessa röskun, sem pýðir að um viðamikið geðheilbrigðisvandamál er að ræða. ${ }^{2}$ Tíðni ADHD-greininga hefur aukist undanfarin ár, sem hefur vakið upp spurningar um hvort vandinn sé ofgreindur nú eða hvort hann hafi verið vangreindur áður., ${ }^{1,3}$

Einkenni ADHD geta verið mismunandi eftir einstaklingum en truflun á einbeitingu, hvatvísi og hreyfióróleiki teljast til helstu greiningarskilmerkja. ${ }^{2}$ Rannsóknir sýna að sé vandinn ekki greindur og viðeigandi meðferð veitt geti pað haft í för með sér ýmiss konar áhættu og skerðingu á lífsgæðum, meðal annars aukið líkur á að einstaklingar misnoti áfengi og vímuefni. ${ }^{4}$ Vegna pess hversu margbreytileg og einstaklingsbundin einkennin geta verið er mælt með pví að meðferð sé fjölpætt og feli meðal annars í sér fræðslu til foreldra og kennara um viðeigandi kennslu- og uppeldisaðferðir, auk pess sem oft er mælt með lyfjameðferð., ${ }^{1,5}$ Örvandi lyf eru sá lyfjaflokkur sem mest er notaður í meðferð ADHD og

${ }^{1}$ Heilbrigðisvísindasviði Háskólans á Akureyri, ${ }^{2}$ menntavísindasviði Háskóla Íslands, ${ }^{3}$ hug- og félagsvísindasviði Háskólans á Akureyri, ${ }^{4}$ Landspítala.

Fyrirspurnum svarar Gísli Kristófersson, gislik@unak.is

https://doi.org/10.17992//bl.2017.12.164

Greinin barst blađinu 7. júní 2017, sampykkt til birtingar 15. nóvember 2017. pykja veita bestu svörun, en til peirra teljast mismunandi lyfjaform af metýlfenídati og amfetamíni. ${ }^{1}$ Á Íslandi er metýlfenídat langmest notaða örvandi lyfið í meðferð ADHD (en pað er til bæði í langverkandi og skammverkandi lyfjaformi. Pekktust eru sérlyfjaheitin Rítalín ${ }^{\circledast}$, Rítalín Uno ${ }^{\circledR}$ og Concerta ${ }^{\circledR} .^{3}$

Samkvæmt upplýsingum úr lyfjagagnagrunni Embættis landlæknis frá vorinu 2017 fengu 9119 einstaklingar ávísað örvandi lyfjum á Íslandi árið 2016 miðað við 5324 einstaklinga árið 2012 sem er rúmlega $72 \%$ hækkun á tímabilinu. Hjá einstaklingum á aldrinum 14-18 ára fengu 839 einstaklingar ávísað örvandi lyfjum árið 2012 en árið 2016 voru peir 1236 sem er 47\% hækkun á tímabilinu. Samkvæmt tölum Hagstofu varð nokkur fækkun í pessum aldurhópi milli 2012 og 2016 og skýrist pessi hækkun pví ekki með fólksfjölgun Íslendinga á pessu aldursbili milli ára. ${ }^{6}$ Samkvæmt tölum Hagstofunnar voru 17.213 börn á aldrinum 14-18 ára árið 2016 á Íslandi en pað pýðir að 7,2\% íslenskra barna á aldrinum 1418 ára höfðu fengið ávísað örvandi lyfjum árið 2016. ${ }^{6}$

Í nýlegri rannsókn á ávísun örvandi lyfja fyrir börn í fjórum löndum Evrópu (Danmörku, Hollandi, Pýskalandi og Bretlandi) og Bandaríkjunum var tíðni ávísana örvandi lyfja 2005/2006 til 2012 borin saman. Samkvæmt niðurstöðum pessarar rannsóknar nota aðeins Bandaríkjamenn svipað magn af lyfseðilsskyldum örvandi lyfjum og Íslendingar í peim aldursflokki sem hér um ræðir, en árið 2012 höfðu 6,5\% bandarískra unglinga á aldrinum 15-19 ára fengið ávísað örvandi lyfjum en aðrar pjóðir voru með mun lægri tíðni (0,5\% til 2,4\%). Pó má sjá að aukin tíðni ávísana er mun skarpari í Evrópulöndunum fjórum á tímabilinu en í Bandaríkjunum. En hún var á bilinu 56,6\% til 302,7\% í Evrópulöndunum á móti 
aðeins 10,7\% hækkun í Bandaríkjunum á tímabilinu. Eins og á Íslandi notuðu Evrópupjóðirnar metýlfenídat nær eingöngu í meðferð ADHD í börnum en Bandaríkjamenn notuðu metýlfenídat og amfetamín jöfnum höndum. ${ }^{7}$

Í rannsókn Helgu Zoëga og félaga var meðal annars skoðuð tíðni ávísana örvandi lyfja fyrir börn fædd á árunum 1994 til 1996 á Íslandi á árunum 2003-2009. Rúmlega 6\% barnanna í rannsókninni höfðu einhverntíma fengið ávísað örvandi lyfjum á tímabilinu en aukning ávísana milli ára var eftirtektarverð. Börnin í yngsta hópnum voru helmingi líklegri til að fá ávísað örvandi lyfjum einhverntíma á tímabilinu miðað við elstu börnin, en $8 \%$ peirra höfðu fengið ávísað örvandi lyfjum á rannsóknartímabilinu. ${ }^{8}$

Í nýlegri rannsókn9 frá árinu 2016 á 521 íslenskum háskólanemum í grunnnámi kemur fram að 13\% peirra hafa misnotað örvandi lyf. Sé litið á pann hóp sem ekki hafði fengið lyfin uppáskrifuð til eigin nota var hlutfallið $11 \%$. Önnur íslensk rannsókn sýnir að metýlfenídat virðist fela í sér síst minni hættu á ávanabindingu en kókaín eða amfetamín pegar pví er sprautað í æð og að peir sem kjósa að misnota metýlfenídat hér á landi kjósi helst langvirkandi útgáfur efnisins. ${ }^{10}$ Einnig sýndu rannsakendur fram á að af peim fíklum sem misnota örvandi efni gegnum æð á Íslandi er metýlfenídat langalgengasta efnið. ${ }^{11}$

Ólögmæt dreifing örvandi lyfseðilsskyldra lyfja hefur verið nánar skilgreind sem millifærsla frá einstaklingum sem pau eru ætluð samkvæmt lyfseðli til annarrar manneskju sem hefur ekki fengið peim ávísað. Petta á við hvort sem lyfin eru seld, peim skipt eða pau gefin. ${ }^{12}$ Pessi hegðun sem heitir diversion á ensku hefur stundum verið kölluð lyfjaflakk á íslensku og munu höfundar halda sig við pessa ágætu pýðingu á hugtakinu í pessari umfjöllun.

Erlendar rannsóknir hafa sýnt að um 7-24\% peirra sem fá ávísað örvandi lyfjum ástunda einhverntíma lyfjaflakk. Almennt má segja að tíðni lyfjaflakks örvandi efna aukist með aldri og sé algengust hjá háskólanemum og öðrum fullorðnum notendum. Breytileikinn í algengi skýrist aðallega af aðferðafræði rannsóknanna og aldri pátttakenda. . $2,13,14^{2}$

Nýleg rannsókn meðal 13-16 ára bandarískra barna benti til að tíðni lyfjaflakks hjá pessum aldursflokki væri um 10\%. ${ }^{12}$ Stór samantektarrannsókn frá 2008 sýndi fram á að tíðni flakks örvandi lyfja fram til 18 ára aldurs sé á bilinu 5-9\%, ${ }^{14}$ á meðan enn önnur nýleg bandarísk rannsókn á meira en 11.000 parlendum börnum á aldrinum 10-18 ára gaf til kynna að um 12\% peirra sem höfðu fengið ávísað örvandi lyfjum höfou einhverntíma ástundað lyfjaflakk. $^{15}$

Hættan af lyfjaflakki er tvípætt. Í fyrsta lagi skapast hætta af pví að einstaklingurinn sem fær lyfjunum ávísað tekur ekki öll lyfin sín sjálf/ur og ADHD-einkennin eru par af leiðandi ómeðhöndluð. Раð getur haft alvarlegar afleiðingar á borð við skert lífsgæði, kvíða, punglyndi, námserfiðleika og hættu á áfengis- og vímuefnamisnotkun. ${ }^{4}$ Í öðru lagi er sú hætta sem fylgir lyfjanotkun án aðkomu eða eftirlits lækna eða annars heilbrigðisfagfólks sem pýðir að notendur eru án ráðgjafar, fræðslu eða eftirlits í notkun sinni á efnunum. Einstaklingar geta ánetjast örvandi lyfjum og misnotkun peirra getur haft í för með sér fjölda hættulegra aukaverkana. Til dæmis má nefna aukna tíðni annarra geðsjúkdóma og félagslegra vandamála auk hættunnar á of stórum skammti sem gæti leitt til alvarlegrar fötlunar eða dauða. ${ }^{16}$ Algengar aukaverkanir örvandi efna eru til dæmis svefnleysi, höfuðverkur, lystarleysi, ýmis einkenni frá hjarta og æðakerfinu eins og háprýstingur og óreglulegur hjartsláttur og geðræn einkenni eins og kvíði, fíkn, og í einhverjum tilfellum geðrof. ${ }^{17}$

Nokkrar erlendar rannsóknir hafa tengt lyfjaflakk við aðra áhættuhegðun eins og vímuefnanotkun. ${ }^{18,19}$ Í rannsókn á lyfjaflakki fólks á tvítugsaldri ${ }^{14}$ kom í ljós að langflestir peirra sem stunduðu slíkt glímdu einnig við fíknisjúkdóma. Pá eru hegðunarvandamál einnig mun algengari í pessum hópi. ${ }^{18}$ Pó ADHD sé mun oftar greint hjá strákum en stelpum hefur ekki tekist að sýna fram á pað með skýrum hætti hvort kynið sé líklegra til að dreifa lyfjunum sínum ólöglega. ${ }^{19}$

Раð eru vitanlega fjölmargar aðrar breytur sem geta haft áhrif á pað hvort unglingur leiðist út í pað að stunda lyfjaflakk. Рað er vel pekkt að stuðningur foreldra er einn helsti áhrifapáttur í heilsu og líðan unglinga. Slíkur stuðningur verkar verndandi í erfiðum aðstæðum, auðveldar aðlögun og dregur úr áhættuhegðun. ${ }^{20}$ Fáar sem engar rannsóknir eru hins vegar til um áhrif tilfinningalegs stuðnings foreldra á lyfjaflakk unglinga.

Pessari rannsókn var ætlað að svara spurningunni hversu algengt lyfjaflakk sé meðal íslenskra unglinga sem fá ávísað örvandi lyfjum. Einnig var skoðað hvort pessi hegðun tengist kyni, tilfinningalegum tengslum við foreldra og notkun vímuefna.

\section{Efniviður og aðferðir}

Hér er byggt á gögnum sem safnað var í íslenskum hluta ESPADrannsóknarinnar (European School Survey Project on Alcohol and Other Drugs) um vímuefnaneyslu 10. bekkinga. Gagnasöfnun fer fram á fjögurra ára fresti í um 40 Evrópulöndum og er studd af Evrópuráðinu. ${ }^{21}$ Rannsóknin er pannig hönnuð að pað eru prenns konar spurningar mögulegar. Í fyrsta lagi eru svokallaðar skylduspurningar (mandatory questions) sem öll lönd verða að leggja fyrir, í öðru lagi geta lönd valið ákveðnar staðlaðar spurningar sem alpjóðlegi rannsóknarhópurinn mælir með (optional questions) og í priðja lagi geta rannsóknarteymi landa sett inn spurningar um efni sem peim finnst sérstaklega áhugaverð (local questions). Spurningarnar sem fjölluðu um lyfjaflakk falla undir priðja flokkinn og er pví um að ræða séríslenska útfærslu.

Í íslenska pýðinu voru 4204 nemendur fæddir árið 1999 sem voru í 266 bekkjardeildum 133 skóla. Nemendur í sérskólum voru ekki hluti pýðisins. Rannsóknin var tilkynnt til Persónuverndar (tilkynning númer 7039) sem óskaði ekki eftir að sótt væri um formlegt leyfi par sem ekki var um persónugreinanleg gögn að ræða. Eftir að skólastjórum allra grunnskóla á Íslandi hafði verið sent kynningarbréf og eintak af spurningalistanum, var haft samband við pá og peir beðnir um leyfi til fyrirlagnar. Pað fékkst hjá 114 skólum sem í voru 179 10. bekkir.

Öllum forráðamönnum var síðan sent upplýsingabréf par sem peim var kynnt efni rannsóknarinnar og gefinn kostur á að hafna pátttöku barna sinna. Að auki var öllum pátttakendum gerð grein fyrir pví á forsíðu spurningalistans að pau pyrftu hvorki að taka pátt né heldur að svara öllum spurningunum. Engir nemendur eða foreldrar peirra höfnuðu pátttöku og fengust svör frá 233610. bekkingum, eða 55,6\% pýðisins. 
Tafla I. Ólögmæt afdrif örvandi lyfja sem ávísað var með lyfseðli.

\begin{tabular}{lcc}
\hline Svör & Fjöldi (n) & $\%$ \\
\hline Dreift með sölu & 13 & 6,3 \\
\hline Dreift með skiptum & 4 & 1,9 \\
\hline Dreift með gjöfum & 9 & 4,3 \\
\hline Ekki tekin, aðeins dreift & 5 & 2,4 \\
\hline Dreift með sölu, skiptum og gjöfum & 5 & 2,4 \\
\hline Samtals & 36 & 17,5 \\
\hline
\end{tabular}

Íslensk pýðing og útfærsla á alpjóðlegum spurningalista var síðan lögð fyrir nemendur í 10. bekk sem mættir voru á fyrirlagnardaginn í pá skóla sem sampykktu pátttöku. Flestir skólanna lögðu listann fyrir í febrúar 2015 en nokkrir í mars. Nemendur svöruðu lista af lokuðum spurningum sem peir fengu í skriflegu formi í kennslustund og skiluðu honum ómerktum í lokuðu umslagi. Kennari eða starfsmaður rannsóknarinnar sáu svo um að safna umslögunum saman.

Spurningin sem fjallað er um í pessari grein var samin af íslenska rannsóknarteyminu, og var svohljóðandi: „Hefur pú einhvern tíma tekið inn örvandi lyf (eins og Rítalín ${ }^{\circledR}$, Rítalín Uno ${ }^{\circledast}$, Concerta ${ }^{\circledR}$ eða Amfetamín) vegna pess að læknir sagði pér að taka pau?" Svarmöguleikarnir voru „Nei aldrei“ og „Já“. Peir sem svöruðu játandi voru svo beðnir um að taka afstöðu til priggja mögulegra dreifingarleiða - „Hefur pú einhvern tíma 1) selt örvandi lyfin pín? 2) skipt örvandi lyfjunum pínum? 3) gefið örvandi lyfin pín?"

Meðal pess sem spurt var um í listanum var neysla á vímuefnum. Pátttakendur voru meðal annars inntir eftir pví hversu oft (ef nokkurn tíma) peir hefðu notað kannabis (marijúana eða hass), amfetamín eða e-töflur (alsælu - ecstacy) um ævina. Peir voru einnig spurðir hvort peir hefðu einhvern tíma á ævinni sniffað (til dæmis lím) til að komast í vímu. Svarmöguleikar voru "Aldrei“, "1-2 sinnum", „3-5 sinnum“, "6-9 sinnum“, „10-19 sinnum“, ,20-39 sinnum“ og "40 sinnum eða oftar". Við úrvinnslu pessara gagna voru pessar breytur gerðar tvígildar, pað er „Prófað einhvern tíma um ævina“ samanborið við „Aldrei prófað“. Spurningar um reykingar og áfengisneyslu voru fjölmargar en pær sem notaðar eru í pessari rannsókn voru hvort unglingarnir hefðu einhverju sinni reykt sígarettur eða drukkið áfengi á síðustu 30 dögum. Svarmöguleikarnir voru peir sömu og að ofan og með sama hætti voru búnar til tvígildar breytur fyrir pessi svör par sem peir sem höfðu reykt sígarettur eða drukkið áfengi í liðnum mánuði voru bornir saman við pá sem ekki höfðu gert pað.

Pátttakendur voru einnig beðnir um að taka afstöðu til fullyrðingarinnar: „Ég á auðvelt með að fá tilfinningalegan stuðning frá foreldrum mínum“. Svarmöguleikar voru: „Næstum alltaf“, "Oft", „Stundum“, „Sjaldan“ og „Næstum aldrei“. Peir sem svöruðu að peir fengju sjaldan eða næstum aldrei slíkan stuðning voru flokkaðir sér undir heitinu „lítill tilfinningalegur stuðningur foreldra".

Tölfræðiforritið SPSS (útgáfa 22) var notað við úrvinnslu gagna. Tíðni og hlutföll voru notuð til að lýsa breytum og kí-kvaðrat til að kanna mun milli hópa. Marktektarmörk voru sett $p<0,01$. Pað svöruðu ekki öll börn öllum spurningum en engar sérstakar grein-
Tafla II. Tengs/ dreifingar örvandi lyfja unglinga við ýmsar breytur.

\begin{tabular}{lc|cc}
\hline & Aldrei fengið lyf & \multicolumn{2}{c}{ Fengið örvandi lyf með lyfseðli } \\
\hline & & Aldrei dreift & Dreift \\
\hline Reykt síðustu 30 daga* & $4,9 \%$ & $11,6 \%$ & $66,7 \%$ \\
\hline Drukkið síðustu 30 daga* & $8,1 \%$ & $16,5 \%$ & $54,3 \%$ \\
\hline Prófað kannabis* $^{*}$ & $6,5 \%$ & $16,9 \%$ & $55,6 \%$ \\
\hline Prófað amfetamín* & $1,3 \%$ & $6,4 \%$ & $45,9 \%$ \\
\hline Prófað e-töflur* $^{*}$ & $1,2 \%$ & $3,5 \%$ & $40,5 \%$ \\
\hline Prófað að sniffa* & $2,7 \%$ & $5,2 \%$ & $37,8 \%$ \\
\hline $\begin{array}{l}\text { Lítill tilfinningalegur } \\
\text { stuðningur foreldra* }\end{array}$ & $6,3 \%$ & $11,4 \%$ & $37,5 \%$ \\
\hline Kvenkyn* & $52,8 \%$ & $29,7 \%$ & $36,1 \%$ \\
\hline
\end{tabular}

*Marktækt miðað við p<0,01 á kí-kvaðrat prófi.

ingar voru gerðar á peim sem slepptu spurningunum sem hér um ræðir.

\section{Niðurstöður}

Alls tóku pátt í könnuninni 2324 unglingar í 10. bekk, par af 1144 drengir og 1180 stúlkur. Af peim svöruðu 2306 (99,2\%) spurningunni: „Hefur pú einhvern tíma tekið inn örvandi lyf (eins og Rítalín, Rítalín Uno, Concerta eða Amfetamín) vegna pess að læknir sagði pér að taka pau?“ Af peim sem svöruðu sögðust 2100 $(91,1 \%)$ aldrei hafa tekið inn slík lyf. Strákar voru rúmlega helmingi líklegri til að hafa fengið örvandi lyf uppáskrifuð en stúlkur, 12,7\% á móti $5,5 \%$.

Alls kváðust 206 einstaklingar hafa fengið örvandi lyf uppáskrifuð frá lækni og af peim höfðu 36 (17,5\%) dreift lyfjunum sínum til annarra. Eins og sést í töflu I var algengast að unglingarnir dreifðu lyfjunum sínum með pví að selja pau (6,3\%). Um 2,4\% peirra sem fengu örvandi lyf höfðu dreift peim á alla pá vegu sem um var spurt og sama hlutfall sagðist aldrei hafa tekið lyfin sjálf en aðeins dreift peim til annarra.

Skoðað var hvort peir nemendur sem dreifðu örvandi lyfjunum sínum skæru sig með einhverjum hætti frá öðrum pátttakendum með tilliti til kyns, tilfinningalegra tengsla við foreldra og annarrar vímuefnanotkunar (tafla II). Í peim tilgangi var hópnum skipt í prennt: 1) Peir sem ekki höfðu fengið uppáskrifuð örvandi lyf, 2) peir sem höfðu fengið örvandi lyf en ekki dreift peim til annarra og 3) Peir sem höfðu fengið örvandi lyf og dreift peim með pví að selja, skipta eða gefa. Í ljós kom talsverður munur sem í öllum tilfellum reyndist marktækur miðað við $p<0,01$ á kí-kvaðrat prófi. Sem dæmi má sjá í töflu II að 4,9\% peirra unglinga sem aldrei höfðu fengið örvandi lyf höfðu reykt á síðustu 30 dögum. Hins vegar höfðu 11,6\% peirra sem höfðu fengið örvandi lyf án pess að dreifa peim reykt á pessu tímabili og $66,7 \%$ peirra sem höfðu dreift. Pannig sést að peir unglingar sem höfðu fengið örvandi lyf frá lækni án pess að dreifa peim til annarra, voru 2-5 sinnum líklegri en peir sem aldrei höfðu fengið slík lyf til pess að hafa reykt $(\mathrm{p}=0,001)$ eða drukkið á síðastliðnum 30 dögum $(\mathrm{p}=0,001)$ eða einhverntíma á ævi sinni prófað kannabis, alsælu ( $\mathrm{p}=0,001)$, amfetamín $(p=0,001)$ eða að sniffa $(p=0,001)$. Pessir nemendur voru einnig nær tvöfalt líklegri til pess að segjast fá lítinn tilfinninga- 
legan stuðning frá foreldrum ( $\mathrm{p}=0,001)$. Hlutfallslega fleiri strákar tilheyrðu einnig pessum hóp ( $\mathrm{p}=0,001)$. Miklu meiri munur sást hins vegar á peim unglingum sem sögðust hafa dreift örvandi lyfjunum sínum. Miðað við pá sem aldrei höfðu fengið slík lyf voru peir sem stundað höfðu lyfjaflakk 7-35 sinnum líklegri til pess að hafa notað áfengi, tóbak eða önnur vímuefni og peir voru 6 sinnum líklegri til pess að segjast fá lítinn tilfinningalegan stuðning frá foreldrum.

\section{Umræða}

Eins og sjá má á niðurstöðum pessarar könnunar er lyfjaflakk örvandi lyfja á meðal 10. bekkinga á Íslandi algengt sé miðað við erlendar rannsóknir par sem algengið liggur á milli 5-12\%.12,13,15,22,23

Samkvæmt niðurstöðum pessarar könnunar á nemendum 10. bekkjar á Íslandi, sögðust um $9 \%$ peirra fá örvandi lyf gegn lyfseðli. Petta passar vel við innlendar tölur um sölu örvandi lyfja en er eilítið hærra en рað sem faraldsfræðilegar rannsóknir gefa til kynna að sé tíðni ADHD í 15 ára gömlum börnum.,24 Jafnvel pó miðað væri við hæstu hugsanlegu tíðni ADHD í börnum sem fram hefur komið í faraldsfræðilegum rannsóknum, má líta svo á að verið sé að meðhöndla nær öll 15 ára börn sem hafa pessa röskun með örvandi lyfjum hér á landi. Раð gefur annaðhvort til kynna afskaplega skilvirkt greiningar- og meðferðarkerfi ADHD í börnum á Íslandi eða mögulega ofgreiningu og ofmeðhöndlun, eftir pví hvernig á pað er litið. Um pað bil 13\% prósent drengja í 10. bekk var ávísað örvandi lyfjum og rúmlega 5\% stúlkna, en pessi kynjamunur er í samræmi við niðurstöður erlendra rannsókna á tíðni ADHD á pessu aldursbili, pó vissulega megi finna bæði hærri og lægri tölur eftir pví hvaða aðferðafræði er beitt hverju sinni. ${ }^{25}$

Samkvæmt niðurstöðum okkar höfðu tæplega 18\% peirra unglinga í 10. bekk sem hafa fengið ávísað örvandi lyfjum ástundað lyfjaflakk á örvandi lyfjunum sínum. Nokkur munur fannst á ávísunum og lyfjaflakki örvandi lyfja eftir kynjum en hlutfall lyfjaflakks er eilítið hærra hjá stúlkum en hjá drengjum. Athuga ber pó að miklu færri stúlkur fá örvandi lyf gegn lyfseðli en drengir, pannig að prósentutala stúlkna er fljótari að breytast en hjá drengjunum. Augljóst er að lyfjaflakk tengist annarri áhættuhegðun eins og reykingum, áfengisneyslu og annarri vímuefnanotkun, pví jafnvel pó peir unglingar sem fá uppáskrifuð örvandi lyf virðist líklegri til að nota vímuefni, eru peir einstaklingar sem dreifa sínum lyfjum í margfalt meiri áhættu. Niðurstöðurnar sýna einnig að lítil tilfinningaleg tengsl við foreldra hafa sterk tengsl við pað að unglingar dreifi örvandi lyfjum.

Petta gefur tilefni til áframhaldandi áherslu á að styrkja tengsl foreldra og barna í æskulýðs- og forvarnarstarfi, sérlega hjá peim börnum sem glíma við ADHD. Einnig að foreldrar, forráðamenn, kennarar og aðrir sem hafa umsjón með börnum á slíkum lyfjum séu vakandi fyrir peim möguleika að barni sé ekki treystandi til að bera sjálft ábyrgð á lyfjunum vegna freistingar um skjótfenginn gróða, félagslegs prýstings eða jafnvel pjófnaðar og hótana frá utanaðkomandi aðilum.

Spurningalistarannsókn sem pessi felur í sér nokkrar augljósar takmarkanir. Í fyrsta lagi er hætta á pví að nemendur svari ekki sannleikanum samkvæmt. Í einhverjum tilfellum tengist slík svörun pví hvað er talið æskilegt innan ákveðins samfélags og getur bæði leitt til pess að svarað er á ýkjukenndan hátt en einnig að dregið sé úr. Sú staðreynd að hér er spurt um ólögmætt athæfi felur einnig í sér pá hættu að skekkja komi í svörin. Rannsóknir á réttmæti ESPAD-spurningalistans, sem meðal annars hafa verið gerðar með pátttöku íslenskra unglinga, benda hins vegar til að líkurnar á svarskekkju hér séu óverulegar og að langflestir svari eins heiðarlega og peim er unnt. ${ }^{21}$ Önnur takmörkun snýr að fjölda pátttakenda par sem tiltölulega fámennur hópur dreifir lyfjunum sínum til annarra og pví varasamt að draga alltof afgerandi ályktanir af niðurstöðunum.

Niðurstöður pessarar könnunar skyldi ekki nota til að gera lítið úr peirri hjálp sem örvandi lyf geta veitt börnum sem glíma við ADHD á pessum aldri. Á sama tíma sýna niðurstöðurnar fram á mikilvægi pess að vandað sé til verka hvað varðar aðbúnað og umgjörð slíkar notkunar, til dæmis aðgengi barna að lyfjunum, sjálfstæði peirra til að skammta sér sjálf lyfin og notkun reglulegra pvagprufa til að sannreyna að barn sé að taka lyfið ef grunur leikur á lyfjaflakki. Ljóst er að til mikils er að vinna, bæði fyrir barnið sjálft og pá sem á ólöglegan hátt komast yfir og neyta lyfjanna sem um ræðir. 


\section{Heimildir}

1. Feldman HM, Reiff MI. Attention deficit-hyperactivity disorder in children and adolescents. N Engl J Med 2014; 370: 838-46.

2. American Psychiatric Association. Diagnostic and statistical manual of mental disorders (DSM-5 $®$ ) American Psychiatric Pub, Arlington 2013.

3. Jóhannsson M, Einarsson ÓB, Guðmundsson LS, Bárðarson L. ADHD og misnotkun lyfja I. Læknablaðið 2013; 99: 537.

4. Chang Z, Lichtenstein P, Halldner L, D'Onofrio B, Serlachius E, Fazel S, et al. Stimulant ADHD medication and risk for substance abuse. J Child Psychol Psychiat 2014; 55: 878-85.

5. Abikoff H, Hechtman L, Klein RG, Weiss G, Fleiss K, Etcovitch J, et al. Symptomatic improvement in children with ADHD treated with long-term methylphenidate and multimodal psychosocial treatment. J Am Acad Child Adolesc Psychiatr 2004; 43: 802-11

6. hagstofan.is - nóvember 2017.

7. Bachmann CJ, Wijlaars LP, Kalverdijk LJ, Burcu M, Glaeske G, Schuiling-Veninga CC, et al. Trends in ADHD medication use in children and adolescents in five western countries, 2005-2012. Eur Neuropsychopharmacol 2017 27: 484-93.

8. Zoëga H, Valdimarsdóttir UA, Hernández-Díaz S. Age, academic performance, and stimulant prescribing for ADHD: a nationwide cohort study. Pediatrics 2012; 130: $1012-8$.

9. Guðmundsdóttir BG. Misnotkun örvandi lyfseðilsskyldra lyfja og ADHD-einkenni meðal háskólanema á Íslandi. Læknablaðið 2016; 102: Fylgirit 89 vegna VI Vísindapings Geðlæknafélag Íslands.
10. Bjarnadottir GD, Magnusson A, Rafnar BO, Sigurdsson E, Steingrimsson $\mathrm{S}$, Johannsson $\mathrm{M}$, et al. Intravenous Use of Prescription Psychostimulants; A Comparison of the Pattern and Subjective Experience between Different Methylphenidate Preparations, Amphetamine and Cocaine. Eur Addict Res 2016; 22: 259-67.

11. Bjarnadottir GD, Haraldsson HM, Rafnar BO, Sigurdsson E, Steingrimsson S, Johannsson M, et al. Prevalent intravenous abuse of methylphenidate among treatment-seeking patients with substance abuse disorders: a descriptive population-based study. J Addict Med 2015; 9: 188.

12. Epstein-Ngo QM, McCabe SE, Veliz PT, Stoddard SA, Austic EA, Boyd CJ. Diversion of ADHD stimulants and victimization among adolescents. J Pediatr Psychol 2016; 41: 786-98.

13. Cassidy TA, Varughese S, Russo L, Budman SH, Eaton TA, Butler SF. Nonmedical Use and Diversion of ADHD Stimulants Among U.S. Adults Ages 18-49: A National Internet Survey. J Atten Disord 2015; 19: 630-40.

14. Wilens T, Gignac M, Swezey A, Monuteaux MC, Biederman J. Characteristics of adolescents and young adults with ADHD who divert or misuse thei prescribed medications. J Am Acad Child Adoles Psychiatry 2006; 45: 408-14.

15. Cottler LB, Striley CW, Lasopa SO. Assessing prescription stimulant use, misuse, and diversion among youth 10-18 years of age. Curr Opin Psychiatry 2013; 26: 511-9.

16. Morton WA, Stockton GG. Methylphenidate Abuse and Psychiatric Side Effects. Prim Care Companion J Clin Psychiatry 2000; 2: 159.

17. lyfjastofnun.is - maí 2017
18. Garnier LM, Arria AM, Caldeira KM, Vincent KB, O'Grady KE, Wish ED. Sharing and selling of prescription medications in a college student sample. J Clin Psychiatr 2010; 71: 262-9.

19. McCabe SE, West BT, Teter CJ, Ross-Durow P, Young A Boyd CJ. Characteristics associated with the diversion of controlled medications among adolescents. Drug Alcohol Depend 2011; 118: 452-8.

20. Stadler C, Feifel J, Rohrmann S, Vermeiren R, Poustka F. Peer-victimization and mental health problems in adolescents: are parental and school support protective? Child Psychiatry Hum Dev 2010; 41:371-86.

21. Hibell B, Guttormsson U, Ahlström S, Balakireva $\mathrm{O}$ Bjarnason T, Kokkevi A, et al. The 2011 ESPAD report substance use among students in 36 european countries. The Swedish Council for Information on Alcohol and Other Drugs, Stokkhólmi 2012

22. McCabe SE, Teter CJ, Boyd CJ. The use, misuse and diversion of prescription stimulants among middle and high school students. Subst Use Misuse 2004; 39: 1095-16.

23. Wilens TE, Adler LA, Adams I, Sgambati S, Rotrosen J, Sawtelle R, et al. Misuse and diversion of stimulants prescribed for ADHD: A systematic review of the literature. J Am Acad Child Adolesc Psychiatry 2008; 47: 21-31.

24. Lasopa SO, Striley CW, Cottler LB. Diversion of prescription stimulant drugs among 10-18-year-olds. Curr Opin Psychiatry 2015; 28: 292-8.

25. Ramtekkar UP, Reiersen AM, Todorov AA, Todd RD. Sex and age differences in attention-deficit/hyperactivity disorder symptoms and diagnoses: implications for DSM-V and ICD-11. J Am Acad Child Adolesc Psychiatry 2010; 49 : 217-28. e3.

\section{ENGLISH SUMMARY}

\section{The diversion of prescribed stimulant medications of 10th graders in Iceland}

Gísli Kristófersson¹, Ársæll Arnarsson², Guðmundur Heimisson³ ${ }^{3}$ Dagbjörg Sigurðardóttir

Introduction: ADHD is a neurodevelopmental disorder that usually surfaces before seven years of age. Stimulants are commonly used medications for the treatment of this disorder in Iceland, but they carry with them a significant risk of both abuse and diversion - i.e. when it is used by an individual other than it was prescribed for by a physician. The purpose of this study was to estimate the prevalence of diversion amongst Icelandic adolescents.

Material and methods: This study is based on data collected in the Icelandic portion of the European School Survey Project on Alcohol and Other Drugs (ESPAD) focused on the drug and alcohol use of $10^{\text {th }}$ graders in Europe.
Results: Of the 2,306 students that participated in the study $91 \%$ $(2,098)$ claimed they had never been prescribed stimulant medications while 9\% (208) claimed they had. Boys were twice as likely to get a stimulant prescription compared to girls. Almost $18 \%$ of the participants that had been prescribed simulants said they had at some point in time diverted their stimulant medication.

Conclusion: The diversion of stimulants by 10th graders in Iceland is quite common compared to studies from other countries where the prevalence is closer to $5-10 \%$. These findings demonstrate the importance of carefully overseeing stimulant use of adolescents, for the benefit of both those who divert as well as those diverted to.

${ }^{1}$ School of Health Sciences, Akureyri, ${ }^{2}$ University of Iceland, Reykjavik, ${ }^{3}$ University of Akureyri, ${ }^{4}$ National University Hospital.

Key words: diversion, stimulants, $A D H D$, adolescents.

Correspondence: Gísli Konráðsson, gislik@unak.is 